\title{
REVIEW
}

\section{To keep the host alive - the role of viral Bcl-2 proteins}

\author{
P. POLČIC, M. MENTEL, G. GAVURNÍKOVÁ, I. BHATIA-KIŠŠOVÁ
}

\begin{abstract}
Department of Biochemistry, Faculty of Natural Sciences, Comenius University in Bratislava, Mlynská dolina CH-1, Ilkovičova 6, 84215 Bratislava, Slovak Republic
\end{abstract}

Received February 2, 2017; accepted April 6, 2017

\begin{abstract}
Summary. - Apoptosis, an intrinsic cellular pathway that eliminates unwanted cells from multicellular organisms, represents an important mechanism for protection against viral infections. When cells infected by viruses get recognized by immune cells, apoptosis is triggered in the infected cells. Among the many regulators of apoptosis involved in this process, a family of proteins homologous to oncogene Bcl-2 plays a central role. Their concerted activities converge to permeabilization of mitochondrial membranes and activation of apoptotic pathways in the presence of diverse apoptotic signals, including virus infection. In the genomes of many viruses, genes encoding for homologues of antiapoptotic proteins of Bcl-2 family can be found. These proteins, collectively referred to as vBcl-2 proteins, inhibit apoptosis in infected cells at the different stages of virus life cycle to enable the virus to complete its replication and to spread.
\end{abstract}

Keywords: apoptosis; vBcl-2; Bcl-2 family; autophagy; virus

\section{Contents:}

1. Introduction

2. Cellular Bcl-2 proteins

3. Autophagy

4. Viral Bcl-2 proteins

4.1 Adenoviridae

4.2 Herpesviridae

4.3 Poxviridae

4.4 Asfarnaviridae

4.5 Birnaviridae

5. Conclusion

E-mail: polcic@fns.uniba.sk; phone: +421-2-60296-398.

Abbreviations: $\mathrm{ADV}=$ adenovirus; $\mathrm{ASFV}=$ African swine fever virus; $\mathrm{BH}=\mathrm{Bcl}-2$ homology motif; $\mathrm{CMV}=$ cytomegalovirus; $\mathrm{EBV}=$ Epstein-Barr virus; KSHV = Kaposi's sarcoma associated herpesvirus; $\mathrm{MHV}-68=$ murine gammaherpesvirus $68 ; \mathrm{MXV}=$ myxoma virus; $\mathrm{VACV}=$ vaccinia virus; $\mathrm{vBcl}-2=$ viral $\mathrm{Bcl}-2$

\section{Introduction}

When infected with viruses, host organisms employ multiple strategies to prevent the virus replication and spread. These include the recognition of infected cells by the host immune system and induction of apoptosis in these cells, eventually leading to the removal of the infection. Viruses, on the other hand, face these strategies either by 'escaping' the recognition and/or by inhibiting the apoptosis of infected cells, which provides the viruses with the opportunity to complete their life cycle and spread. Genomes of many viruses, thus, encode for multiple proteins capable of inhibition of different steps of the host apoptotic pathway. While some viruses inhibit the execution of apoptosis by inhibiting caspases - proteases involved in execution of apoptosis, many viruses are known to inhibit regulatory proteins upstream of the activation of caspases. The most prominent among these regulatory proteins are the proteins of the Bcl-2 family. 


\section{Cellular Bcl-2 proteins}

Proteins of the $\mathrm{Bcl}-2$ family are involved in the regulation of apoptosis. They integrate many distinct cell death-inducing signals and translate them into a single universal apoptosisinducing event - permeabilization of mitochondrial outer membrane, which results in release of the cytochrome $c$ and several other apoptogenic proteins from mitochondrial intermembrane space to the cytosol. Binding of cytochrome $c$ to the cytosolic protein Apaf-1 then induces the formation of heptameric complexes, apoptosomes, activating procaspase 9 and downstream caspases (Fig. 1) (see e.g. Youle and Strasser, 2008 for review).

Founding member of the Bcl-2 family, Bcl-2, is an apoptosis-inhibiting protein first identified in patients with B-cell lymphoma (Bakhshi et al., 1985; Cleary and Sklar, 1985;
Tsujimoto et al., 1985). Other members of this protein family share structural similarity with Bcl-2 in at least one of four distinct $\mathrm{BH}$ (Bcl-2 homology) motifs (BH1-BH4). According to their activity, particular $\mathrm{Bcl}-2$ family proteins fall into one of three subfamilies, in which the functions correlate with the presence of individual $\mathrm{BH}$ domains. Subfamily of multimotif proapoptotic proteins (also known as Bax subfamily) consists of Bax (Bcl-2-associated X protein), Bak (Bcl-2 homologous antagonist / killer) and several other proteins containing three BH motifs (BH1-BH3) (Youle and Strasser, 2008). Activity of these proteins results in the permeabilization of mitochondrial membranes and release of cytochrome $c$ and other apoptogenic factors from mitochondria. Of these proteins, Bax and Bak are absolutely required for membrane permeabilization, as double knock-out $\left(\mathrm{Bax}^{-/-} \mathrm{Bak}^{-/}\right)$cells are resistant to all inducers of mitochondrial apoptotic pathway

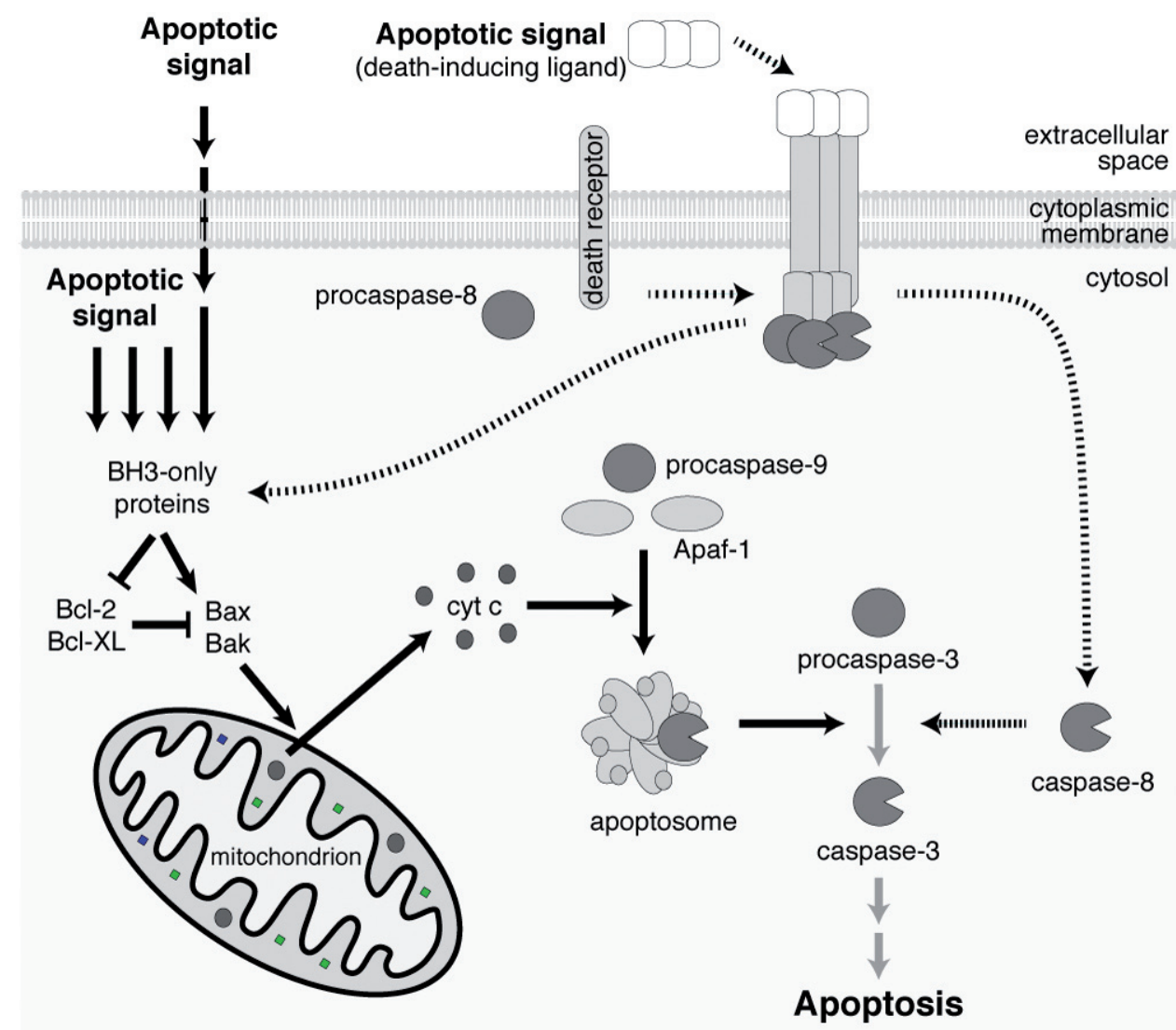

Fig. 1

Apoptosis-inducing pathways

Extrinsic (receptor) pathway of apoptosis (dotted arrows) begins with ligation of receptors of the tumor necrosis factor receptor (TNFR) superfamily that induces oligomerization and activation of initiator caspase 8 , which then activates downstream executioner caspases (e.g. caspase 3 ). In intrinsic (mitochondrial) pathway (full arrows), distinct proapoptotic signals are sensed by proteins of the Bcl-2 family that induce permeabilization of the outer mitochondrial membrane, releasing cytochrome $c$ and several other apoptogenic proteins into the cytosol. Cytochrome $c$ in cytosol induces the formation of apoptosome and activation of downstream caspases. 
(Lindsten et al., 2000; Wei et al., 2001). Subfamily of antiapoptotic proteins (Bcl-2 subfamily) consists of proteins $\mathrm{Bcl}-2, \mathrm{Bcl}-\mathrm{XL}, \mathrm{Bcl}-\mathrm{w}, \mathrm{MCL}-1$ and $\mathrm{A} 1$ that act to prevent the release of the cytochrome $c$ from mitochondria in living cells and contain all four BH motifs (BH1-BH4). Proteins of remaining subfamily are proapoptotic proteins, e.g. Bid, Bim, Bik, Bad, which contain only BH3 motif, and are therefore collectively referred to as $\mathrm{BH} 3$-only proteins. These proteins regulate the activity of the two above-mentioned subfamilies in response to a wide range of signals, resulting in activation of multimotif proapoptotic proteins Bax and Bak, culminating in Bax and Bak oligomerization in outer mitochondrial membrane and membrane permeabilization.

The intracellular localization of Bcl-2 family proteins is diverse. Antiapoptotic proteins reside in intracellular membranes, in which they are anchored by C-terminal hydrophobic transmembrane domain. While Bcl-2 localizes to all intracellular membranes, Bcl-XL is specifically targeted to outer mitochondrial membrane (Kaufmann et al., 2003). Multimotif proapoptotic protein Bax is localized in the cytosol in living cells and upon induction of apoptosis is translocated into mitochondrial membrane (Hsu et al., 1997; Wolter et al., 1997). Bak, the other multimotif proapoptotic protein, is, however, associated with mitochondrial

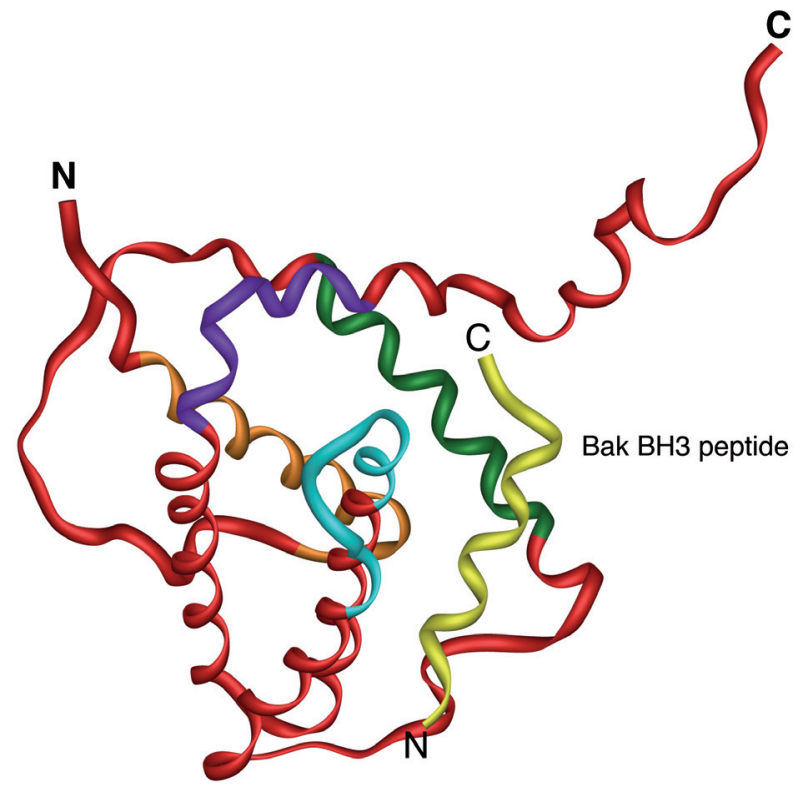

Fig. 2

Three-dimensional structure of antiapoptotic Bcl-2 family protein Crystal structure of $\mathrm{Bcl}-\mathrm{XL}$ with indicated position of individual $\mathrm{BH}$ motifs ( $\mathrm{BH} 1$ blue; $\mathrm{BH} 2$ purple; $\mathrm{BH} 3$ green and $\mathrm{BH} 4$ orange) is shown. Yellow a-helix represents a Bak-derived $\mathrm{BH} 3$ peptide bound in the hydrophobic groove of $\mathrm{Bcl}-\mathrm{XL}$. C-terminal hydrophobic domain is replaced with $6 \mathrm{xHis}$ tag. Picture was generated by iMol 0.40 software using structural data from Sattler et al. (1997). membrane even in the absence of apoptosis-inducing signals. Intracellular localization of $\mathrm{BH} 3$-only proteins reflects their function in sensing various apoptosis-inducing signals. Most of them are present in cytosol and after receiving apoptosisinducing signal translocate to the surface of mitochondria, where they interact with other pro- or antiapoptotic proteins of the Bcl-2 family, which results in activation of Bax and Bak and ultimately in permeabilization of the membrane. Translocation of these proteins from cytosol is mostly regulated by posttranslational modifications. Bid, for example, is a cytosolic protein that is, in response to the activation of death receptors on the cell surface, activated by proteolytic cleavage by caspase 8 . Cleavage of Bid produces active truncated form of Bid - tBid, in which newly generated $\mathrm{N}$-terminus is myristoylated, targeting the protein to the mitochondrial membrane (Zha et al., 2000). Activation and translocation of other $\mathrm{BH} 3$-only proteins, e.g. Bad, Bim and $\mathrm{Bmf}$, may in response to the apoptotic signal be regulated by phosphorylation/dephosphorylation, and yet another $\mathrm{BH} 3$-only proteins may be active without posttranslational modification and be regulated at the level of transcription (e.g. p53-induced transcription of Puma and Noxa).

Interestingly, three-dimensional structure of multimotif proteins of the $\mathrm{Bcl}-2$ family is similar for both proapoptotic (Bax and Bak) (Suzuki et al., 2000) and antiapoptotic proteins (e.g. Bcl-2, Bcl-XL) (Muchmore et al., 1996), consisting of two hydrophobic $\alpha$-helices surrounded by seven amphiphatic helices (Fig. 2). The overall fold of these proteins resembles the structure of pore-forming domains of bacterial toxins such as colicins or diphtheria toxin. Upon interaction with the membrane, these proteins rearrange and get integrated into membrane by hydrophobic $\alpha$-helices.

Of the BH3-only proteins, structure of $\mathrm{tBid}$ is similar to the structure of multimotif proapoptotic and antiapoptotic proteins (Chou et al., 1999; McDonnell et al., 1999), while others are mostly intrinsically unstructured proteins that only undergo limited conformational change when interacting with other proteins, e.g. binding other Bcl-2 family members (Hinds et al., 2007).

The mechanisms, by which $\mathrm{BH} 3$-only proteins activate Bax and Bak remain under dispute. All proposed models reflect the fact that the $\mathrm{BH} 3$ domains are capable of binding into the hydrophobic groove in multimotif proteins (Fig. 2). The 'direct activation' model proposes that activated $\mathrm{BH} 3$ only proteins directly bind to the inactive monomeric Bax and Bak, inducing their oligomerization and membrane insertion to form a pore in the outer mitochondrial membrane. In model of 'indirect activation', $\mathrm{BH} 3$-only proteins bind to antiapoptotic proteins, such as Bcl-XL and Bcl-2 to inhibit their antiapoptotic activity, activating, thus, Bax and Bak indirectly. As it appears that these two models are not mutually exclusive, other models assume that while some of the BH3-only proteins may act as 'activators' to directly 
activate Bax and Bak, others, called 'sensitizers', may act by an indirect mechanism (Willis and Adams, 2005; Aouacheria et al., 2013).

Among BH3-only proteins, one protein - Beclin-1 - stands out as it plays a key role in the regulation of autophagy, connecting thus the regulation of programmed cell death and autophagy.

\section{Autophagy}

Autophagy is an essential and evolutionarily conserved process characterized by the intracellular accumulation of double-membrane vesicles called autophagosomes that engulf cytoplasmic material including proteins, large macromolecular aggregates and even entire organelles. Autophagosomes with cargo are targeted to lysosomes for degradation and recycling. Under normal conditions, autophagy operates at a basal level to eliminate long-lived proteins and to maintain cellular homeostasis. In response to various forms of stress, including starvation, depletion of growth factors, low energy levels, hypoxia, oxidative stress or ER stress, autophagy is upregulated to provide a cell-autonomous source of energy and amino acids (Yang and Klionsky, 2010).

Several proteins coordinate and regulate autophagy in mammals. The key role in the regulation of autophagy lies with the BH3-only protein Beclin-1 due to its ability to interact with various partners, especially with class III phosphoinositide-3-kinase (PI3K), together with Vps34, Vps15 and Ambra1, to form a complex responsible for autophagosome formation (He and Levine, 2010).

Several studies have also implicated autophagy in innate and adaptive immune response against pathogens (Levine and Deretic, 2007). However, increasing evidence suggests that viruses have evolved diverse strategies not only to evade or subvert autophagy but also to take advantage of this cellular process (Liang et al., 2015a).

Cellular Bcl-2, the prototype apoptosis inhibitor, has been demonstrated to be an interconnection between autophagy and apoptosis as it negatively regulates autophagy by binding to the $\mathrm{BH} 3$ domain of Beclin-1 autophagic protein (Pattingre et al., 2005).

\section{Viral Bcl-2 proteins}

In many viruses homologues of antiapoptotic proteins of the Bcl-2 family, collectively referred to as vBcl-2 (viral Bcl-2) proteins, have been identified. These viral proteins differ significantly in their primary structure and include those that are closely homologous with cellular antiapoptotic proteins, proteins that contain some of $\mathrm{BH}$ motifs, as well as proteins, in which no sequence homology can be identified. All of these proteins, however, contain a fold typical for antiapoptotic proteins of the Bcl-2 family. It is, thus, similarity of the three-dimensional structure, rather than sequence similarity, which is important for their antiapoptotic function.

\subsection{Adenoviridae}

The first viral Bcl-2 protein was identified in adenovirus (ADV). Adenoviruses are small DNA oncogenic viruses that infect mammals and birds. Human adenoviruses mainly infect epithelial cells of the respiratory and gastrointestinal tract, in which they can establish persistent infection.

In the cell lines, infection results in progressive replication. The early genes, expressed after the virus entry, involve $\mathrm{E} 1 \mathrm{~A}$ and E1B. Expression of E1A is required for the replication of viral genome but it induces the apoptosis of host cells. Mutants of adenovirus with altered gene encoding for one of the proteins encoded by E1B, E1B-19K, were described, in which the degradation of cellular DNA and cytopathy resembling the apoptosis were observed (White et al., 1984). E1B-19K thus appeared to block apoptosis in infected cells, sustaining the viral replication.

The E1B-19K is a protein that displays limited sequence similarity to Bcl-2 proteins (Chiou et al., 1994), containing sequences homologous to $\mathrm{BH} 1$ and $\mathrm{BH} 3$ motifs of cellular Bcl-2. Phenotypes observed in E1B-19K mutants can be suppressed by either coexpression of cellular Bcl-2 or in transgenic virus, in which native E1B coding sequence was replaced with that encoding for cellular Bcl-2 (Chiou et al., 1994; Subramanian et al., 1995b), indicating that E1B-19K and cellular Bcl-2 are functional homologs. Moreover, recombinant proteins constructed from E1B-19K and cellular $\mathrm{Bcl}-2$ by replacing a conserved sequence motif in one by corresponding region of the other retain their antiapoptotic activity (Subramanian et al., 1995a).

Similarly to cellular Bcl-2, when E1B-19K is expressed in the cell lines it is able to suppress the apoptosis induced by E1A expression or other stimuli, including treatment with death receptors ligands, such as tumor necrosis factor- $\alpha$ (White et al., 1991, 1992).

During an adenoviral infection, E1B-19K also interacts with Beclin-1 in the host cells, resulting in modulation of the interaction of Beclin-1 with PI3K complex, and subsequent initiation (in opposite from what is described for other viral Bcl-2 proteins) of autophagy and the formation of autophagosomes. The mechanisms, by which E1B-19K promotes autophagy, involve antagonizing cellular Bcl-2 protein through direct competition to heterodimerize with Beclin-1. Functional BH3 domain of E1B-19K is required for this interaction (Piya et al., 2011). Adenoviruses, thus, have evolved their own mechanism to trigger autophagy, which might be required for viral replication and/or cell lysis (Piya et al., 2011; Liang et al., 2015a). 


\subsection{Herpesviridae}

Herpesviruses are a family of DNA viruses causing diseases in humans and animals. While individual herpesvirus subfamilies target different cell types, the common feature of all is their ability to establish latency in the host cell.

Kaposi's sarcoma-associated herpesvirus (KSHV), also known as human herpesvirus $8(\mathrm{HHV}-8)$, is a tumorigenic gammaherpesvirus linked to human cancers including Kaposi's sarcoma, primary effusion lymphoma and some forms of Castleman's disease (Damania and Cesarman, 2013). In KHSV genome, an open reading frame orf16 encodes for KSBcl-2 (Kaposi's sarcoma-associated Bcl-2). The protein contains conserved $\mathrm{BH} 1$ and $\mathrm{BH} 2$ motifs and a stretch of hydrophobic amino acids followed by basic amino acids that may anchor the protein into intracellular membranes at its C-terminus (Cheng et al., 1997; Sarid et al., 1997).

Transgenic expression of KSBcl-2 inhibits apoptosis induced by Sindbis virus infection of BHK cells to the extent comparable to overexpression of cellular Bcl-2 or Bcl-XL (Cheng et al., 1997), it inhibits apoptosis of fibroblasts induced by transfection with Bax, as well as it inhibits killing of yeast cells by ectopically expressed human Bax (Sarid et al., 1997). KSBcl-2 does not form dimers, nor it forms heterodimers with Bax or Bak (Cheng et al., 1997), but can bind Beclin-1 (Pattingre et al., 2005; Sinha et al., 2008).

Expression of KSBcl-2 was detected when cell line latently infected with KSHV was treated with phorbol ester that induces reactivation of the virus, indicating that it is expressed during lytic cycle (Cheng et al., 1997). Experiments using mutant viruses with inactivated orf16 demonstrated that while $\mathrm{KSBcl}-2$ is dispensable for establishment of latent infection, it is required for virus reactivation. Mechanisms involved in this function likely include other than blocking apoptosis, because mutant with deleted orf16 has defect in reactivation and does not express some of reactivationspecific proteins (which are therefore likely regulated by KSBcl-2) (Gelgor et al., 2015).

$\mathrm{KSBcl}-2$ was the first viral protein reported to be able to inhibit autophagy by directly interacting with Beclin-1 via the $\mathrm{BH} 3$-binding hydrophobic surface groove of $\mathrm{vBcl}-2$, in both yeast and mammalian cells (Pattingre et al., 2005) (see below for the details).

Epstein-Bar virus (EBV), also called human herpesvirus 4 (HHV-4), is another highly prevalent human gammaherpesvirus infecting B-lymphocytes. Normally the infection is either asymptomatic or leads to a benign lymphoproliferation (infectious mononucleosis) but in immuno-compromised individuals may cause several types of cancer, including Hodgkin's lymphoma, Burkitt's lymphoma and nasopharyngeal carcinoma (Longnecker et al., 2013). Unlike in other gammaherpesviruses, two homologs of $\mathrm{Bcl}-2$ have been identified in EBV. BHRF1 has structural homology with cellular Bcl-2 and Bcl-XL in BH1-BH3 (Marshall et al., 1999). Its expression enhances survival in transfected Burkitt's lymphoma-derived cell lines in conditions that normally trigger apoptosis, such as low serum and treatment with ionomycin (Henderson et al., 1993). Cell lines expressing BHRF1 are also resistant to $\gamma$-irradiation, treatment with cytosine arabinoside (Ara-C), doxorubicin, etoposide and staurosporine, similarly to those overexpressing Bcl-2, Bcl-XL or Bcl-W (Kvansakul et al., 2010).

Solution of three-dimensional structure has revealed that BHRF1 has an overall structure similar to cellular Bcl-2 proteins, but differs significantly in the structure of the hydrophobic groove, which is why BHRF1 does not bind tightly to peptides derived from Bak, Bax, Bik and Bad (Huang et al., 2003). Later it was demonstrated that BHRF1 binds BH3-only protein Bim (Desbien et al., 2009) and the importance of the interaction of the hydrophobic groove was further corroborated when an artificial peptide inhibitor designed to bind to BHRF1 hydrophobic groove was shown to induce apoptosis in EBV-infected cells (Procko et al., 2014). It is, however, not unlikely, that mechanisms of its antiapoptotic activity also include ones that differ from those of other antiapoptotic $\mathrm{Bcl}-2$ proteins, including e.g. downregulation of expression of proapoptotic protein Noxa (Yee et al., 2011).

In addition to BHRF1, another Bcl-2 homologue - BALF1 - was identified in EBV genome (Marshall et al., 1999). Unlike most of the other vBcl-2s, BALF1 contains all BH motifs but lacks C-terminal hydrophobic domain. When expressed in cultured cells, BALF1 protects cells from apoptosis induced by treatment with interferon $\gamma$ and anti-Fas antibody (Marshall et al., 1999) and renders transfected cells' growth serum independent (Cabras et al., 2005).

Both EBV antiapoptotic proteins appear to be required to prevent apoptosis during initial infection of lymphocytes (Altmann and Hammerschmidt, 2005). As the expression of both, BHRF1 and BALF1, was detected in the Burkitt's lymphoma cell lines and in some other EBV-associated tumor cells, it is likely that they also play an important role in EBVinduced oncogenesis (Cabras et al., 2005; Hsu et al., 2012).

It has not been reported yet whether the two viral homologues of Bcl-2 encoded by EBV have influence on autophagy. However, owing to their structural and functional homology to cellular Bcl-2, it seems likely that BHRF1 and BALF1 may also have an antiautophagy activity. Nevertheless, they could be responsible for the initial autophagy inhibition that was observed early after the expression of EBV early lytic products in Burkitt's lymphoma cells (Nowag et al., 2014).

Besides KSHV and EBV, homologues of Bcl-2 have been found in genomes of all gammaherpesviruses. Of these, murine gammaherpesvirus 68 (MHV-68), also referred to as murid herpesvirus $4(\mathrm{MuHV}-4)$, represents an important 
model virus, because, unlike human herpesviruses, it can also be studied in vivo in its natural host. In MHV-68, the protein encoded by gene M11 has been identified as an homologue of Bcl-2 proteins with limited homology to cellular Bcl-2 proteins in $\mathrm{BH} 1$ motif and was shown to inhibit apoptosis induced by various stimuli involving FAS ligation, TNF- $\alpha$ treatment (Wang et al., 1999), Sindbis virus infection (Bellows et al., 2000), $\gamma$-ray irradiation, dexamethasone treatment or CD3e ligation (Loh et al., 2005). Although sequence similarity of M11 with cellular Bcl-2 proteins is rather weak and only restricted to $\mathrm{BH} 1$ motif, three-dimensional structure of M11 is very similar to the structure of cellular antiapoptotic Bcl-2 family member Bcl-XL (Loh et al., 2005). Cell-based binding assays as well as in vitro binding assays using peptides derived from $\mathrm{BH} 3$ domains of $\mathrm{Bcl}-2$ family proteins have shown that M11 protein can bind to the regulator of autophagy Beclin-1 and to proapoptotic proteins of the Bcl-2 family, including multimotif proapoptotic proteins Bak, Bax and several BH3only proteins, e.g. Bid, Noxa, Bim, Bmf and Puma. While the role of M11 in inhibition of autophagy by interacting with Beclin-1, which binds to M11 with the highest affinity, has been well established (Ku et al., 2008; Sinha et al., 2008), functional interactions of M11 with regulators of apoptosis have not been well characterized.

M11 is expressed during latency (Virgin et al., 1999; Marques et al., 2003), appears not to be required for replication of the virus (Gangappa et al., 2002; de Lima et al., 2005), but is required for in vivo persistence in immune-deficient mouse (Gangappa et al., 2002).

Using mutants deficient in M11 it was shown that M11 may play important role in infection of immature and transitional B-cells, in which it inhibits B-cell receptor-mediated apoptosis (Coleman et al., 2014).

Similarly to KSBcl-2, M11 was also shown to inhibit autophagy through its interaction with Beclin-1 (Sinha et al., 2008). Whereas the interaction between cellular Bcl-2 and Beclin-1 is regulated by the phosphorylation of the three different Bcl-2 sites (at residues T69, S70, and S87 of the non-structured loop) when cells are subjected to stress, such as starvation, KSBcl-2 and M11 lack analogous phosphorylation sites (Wei et al., 2008). This results in a stable interaction between these vBcl-2s and Beclin-1, leading to a constitutive repression of autophagy. Unlike its cellular counterpart, the vBcl-2-Beclin-1 complex can not be easily disrupted by other BH3-only molecules, such as Bid or Bim (Ku et al., 2008). As a result, these viral homologues exhibit an enhanced capacity for autophagy inhibition as compared to cellular Bcl-2 (Liang et al., 2008).

Mutations in the central hydrophobic cleft of herpesvirus genome-encoded vBcl-2s (84WGR86 of KSBcl-2 or 85SGR87 of M11) perturb the structure of the BH3-peptide-binding groove and prevent the interaction with Beclin-1, resulting in the release of the inhibition of autophagy (E et al., 2009).
Furthermore, a Beclin-1-binding deficient mutant MHV-68 strain, which is impaired in autophagy inhibition but retains intact antiapoptotic activity, is compromised in the ability to maintain chronic infection, though the initial viral establishment of latency is not affected. In contrast, a mutant virus lacking the antiapoptotic activity of vBcl-2 establishes chronic infection as efficiently as the wild-type virus but is largely impaired in efficient ex vivo reactivation from latency (Liang et al., 2015b). Thus, while the M11 protein does not appear to be indispensable for lytic replication or for acute infection in vivo, its antagonism of autophagy confers chronic/persistent infections (E et al., 2009; Liang et al., 2015b).

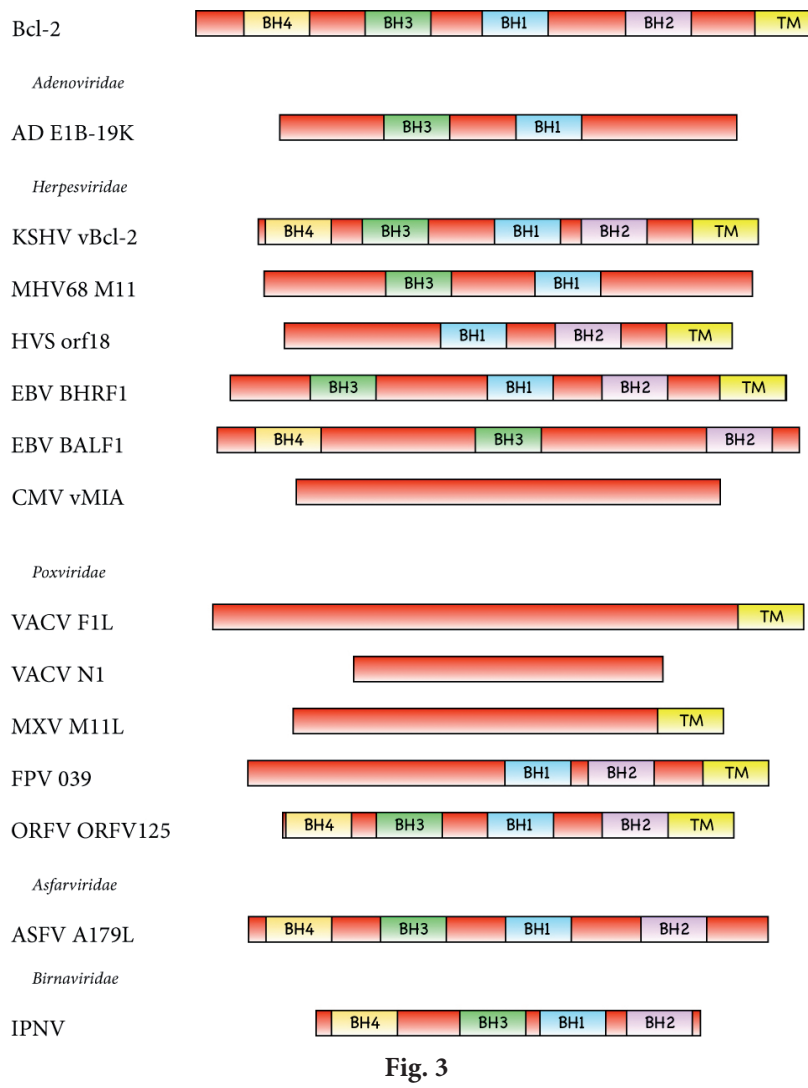

Bcl-2 homology motifs within viral Bcl-2 proteins

Identified Bcl-2 homology motifs (BH1-BH4) and C-terminal transmembrane domains (TM) present in cellular Bcl-2 (Bcl-2) and its viral homologs: adenovirus E1B-19K (AD E1B-19K), Kaposi's sarcoma-associated herpesvirus vBcl-2 (KSHV vBcl-2), murine gammaherpesvirus 68 M11 (MHV-68 M11), herpesvirus saimiri orf18 (HVS orf18), Epstein-Bar virus BHRF1 (EBV BHRF1), Epstein-Bar virus BALF1 (EBV BALF1), human cytomegalovirus vMIA (CMV vMIA), vaccinia virus F1L (VACV F1L), myxoma virus M11L (MXV M11L), fowlpoxvirus 039 (FPV 039), ORF virus ORFV125 (ORFV ORFV125), African swine fever virus A179L (ASFV A179L) and infectious pancreatic necrosis virus VP5 (IPNV) are indicated. The lengths of proteins correspond to the molecular weights of individual proteins, while the lengths of $\mathrm{BH}$ motifs correspond to the lengths of $\mathrm{BH}$ motifs in human Bcl-2. 
Surprisingly, KSBcl-2 differs from other vBcl-2 proteins in that it is essential for viral replication, as its knockout dramatically lowers KSHV lytic gene expression, viral DNA replication, and progeny virus production (Gelgor et al., 2015; Liang et al., 2015b). Most importantly, it has been found that this novel essential function of KSBcl-2 in lytic replication is separate from the apoptosis- and autophagy-inhibiting activity but correlates with an unusual localization within the cell nucleus (in addition to mitochondria) of infected cells, suggesting that this protein might execute its essential function in the nucleus (Gallo et al., 2017).

Yet different antiapoptotic protein has been found in human cytomegalovirus (CMV), also known as human herpesvirus 5 (HHV-5), an important pathogen that causes significant mortality in immunocompromised individuals and a leading viral cause of congenital defects (Mocarski et al., 2013). Viral mitochondria-localized inhibitor of apoptosis (vMIA) in CMV is encoded by open reading frame UL37x1 (Goldmacher et al., 1999). Orthologous protein is encoded by m38.5 in murine cytomegalovirus (MCMV). vMIA has no homology to cellular Bcl-2 proteins, but likely has a fold typical for Bcl-2 proteins (Pauleau et al., 2007). Unlike other antiapoptotic proteins, vMIA was shown to recruit Bax to mitochondria and bind it, but preventing it from formation of pores in mitochondrial membranes (Arnoult et al., 2004). It selectively binds Bax but not Bak (Arnoult et al., 2004), binding to a unique non-canonical binding site (Ma et al., 2012).

Later analyses have shown that vMIA is synthesized at endoplasmic reticulum (ER), from where it traffics to mitochondria-associated subdomains of ER (mitochondriaassociated membranes, MAM) at the contact sites of ER and mitochondria and to mitochondria (Mavinakere et al., 2006), where it associates with lipid rafts (Williamson et al., 2011). It has been shown that in cells infected with CMV, vMIA is recruiting Bax to MAM and likely targets Bax for proteosomal degradation (Zhang et al., 2013).

Due to the strict host specificity of CMV, the activity of vMIA in vivo cannot be studied directly and the murine virus can be used as a useful model. In mice infected with MCMV, $\mathrm{m} 38.5$ is required for effective replication in leukocytes, while it appears to be dispensable for replication in visceral organs. As leukocytes represent a route of virus to the salivary glands, through which the virus is being disseminated, $\mathrm{m} 38.5$ is required to generate sufficient titer of the virus in salivary glands and efficient dissemination (Manzur et al., 2009).

In addition to Bax-specific m38.5, another antiapoptotic protein localizing to mitochondria and specifically inhibiting Bak - m41.1, also known as vIBO (viral inhibitor of Bak oligomerization), was identified in MCMV (Cam et al., 2010). This 57-amino-acid protein, however, does not represent a Bcl-2 homolog as it shares no homology with $\mathrm{Bcl}-2$ proteins and due to its low molecular weight must not be able to fold like Bcl-2 proteins. When expressed in cultured $\mathrm{Bax}^{-/}$cells, $\mathrm{m} 41.1$ protects cells from apoptosis (Fleming et al., 2013). Antiapoptotic activity of m41.1 has been shown to be required for optimal virus replication in infected animals in leukocytes in blood and spleen, as well as in lungs and liver. MCMV thus expresses two antiapoptotic proteins, one for inhibition of Bax and one for inhibition of Bak with different requirement for these proteins in different tissues reflecting the different involvement of Bax and Bak in these tissues (Fleming et al., 2013). Interestingly, no Bak-specific antiapoptotic protein has been identified in human CMV so far.

Although the first report suggesting a possible relationship between human CMV and autophagy appeared in 1978 (Smith and de Harven, 1978), it took 30 years to demonstrate that CMV produces a marked blockade of autophagy (Chaumorcel et al., 2008). Despite the fact that other herpesviruses, such as KSHV and MHV-68, express a viral homolog of Bcl-2 able to block autophagy, CMV does not posses one - vMIA does not have that ability (Chaumorcel et al., 2012).

Although CMV stimulates the expression of cellular Bcl-2 protein, which has an anti-autophagy effect via its interaction with Beclin-1, it does not use this strategy to block the autophagy. It has been shown that the TRS1 protein of human CMV blocks autophagosome biogenesis through its binding to Beclin-1 and that a TRS1 deletion mutant is defective in autophagy inhibition (Chaumorcel et al., 2012).

\subsection{Poxviridae}

Poxviruses are large DNA viruses that infect animals and cause often fatal diseases. A prototype of poxviruses is vaccinia virus (VACV). An antiapoptotic gene F1L, protecting infected cells from apoptosis induced by intrinsic pathway inducer staurosporine, was identified by screening a set of deletion mutants of VACV strain lacking a gene encoding for a caspase 8 inhibitor CrmA (Wasilenko et al., 2003). F1L encodes for a protein that bears no sequence homology with cellular Bcl-2 except for a C-terminal hydrophobic membrane anchor and localizes to mitochondria to inhibit the release of cytochrome $c$ (Wasilenko et al., 2003). The mitochondrial localization appears to be required for the antiapoptotic activity of F1L (Stewart et al., 2005). The crystal structure of F1L revealed that protein assumes a Bcl-2 fold and forms a dimer with swapped helices (a1) (Kvansakul et al., 2008). The dimers of F1L contain two hydrophobic grooves capable of binding $\mathrm{BH} 3$ peptides derived from Bim or Bak (Wasilenko et al., 2005; Postigo et al., 2006; Campbell et al., 2014). In addition to inhibiting the cell death-inducing activity of Bim and Bak, F1L was found to inhibit caspase 9 by binding it by a novel motif at the N-terminus of F1L (Zhai et al., 2010; Yu et al., 2011). F1L was shown to partially protect the cells from Bax-dependent cell death, while not to bind Bax. This effect, 
thus, likely reflects combined inhibition of Bim and caspase 9 (Taylor et al., 2006; Zhai et al., 2010).

Second antiapoptotic protein in VACV is N1 encoded by gene N1L. It was described as a virulence factor, which is not required for virus replication in cell culture, but deletion mutant is attenuated in intranasal and intradermal mouse model (Bartlett et al., 2002). Although it also does not contain recognizable $\mathrm{BH}$ motifs, its three-dimensional structure strikingly resembles that of cellular Bcl-2 proteins, and it forms homodimers (Aoyagi et al., 2007; Cooray et al., 2007). During viral infection, N1 binds endogenous Bid, Bak and Bax as well as ectopically overexpressed Bad and Bax (Cooray et al., 2007). Inhibition of apoptosis, however, may not be the most crucial contribution of N1 to virulence, as in addition to inhibition of apoptosis, N1 also inhibits pro-inflammatory signaling by inhibiting nuclear factor- $\kappa B$ $(\mathrm{NF}-\kappa \mathrm{B})$ activation. The latter function is independent on $\mathrm{N} 1$ antiapoptotic function and employs different surface of N1 protein (Maluquer de Motes et al., 2011).

Myxoma virus (MXV) is a member of the Leporipox virus genus, which infects rabbits and causes lethal myxomatosis. One of the genes required for its virulence is $\mathrm{M} 11 \mathrm{~L}$, as rabbits infected with M11L knock-out virus develop a mild form of the disease, from which they may fully recover (Opgenorth et al., 1992). M11L encodes for a 166-amino acid protein that contains hydrophobic C-terminal domain, which targets protein to the mitochondria, but otherwise bears no homology to Bcl-2 proteins (Everett et al., 2000). The solved crystal structure of M11L shows that its three-dimensional structure closely resembles the structure of cellular antiapoptotic proteins Bcl-2 or Bcl-XL (Douglas et al., 2007). Either transient expression or infection with MXV protects cells from apoptosis induced by number of different stimuli (Everett et al., 2002; Su et al., 2006) by inhibiting activation of Bax (Su et al., 2006) and Bak (Wang et al., 2004).

Fowlpox virus (FPV) is a prototypical virus of the family Avipoxviridae, infecting poultry. Based on sequence analysis of the genome, the gene FPV039 has been identified as Bcl-2 homologue. Unlike antiapoptotic proteins of above-mentioned poxviruses, FPV039 contains highly conserved BH1 and $\mathrm{BH} 2$ motifs and C-terminal transmembrane domain. FPV039 has no obvious homology with $\mathrm{BH} 3$ and BH4 motifs (Banadyga et al., 2007). When expressed in cultured human or chicken cells, FPV039 localizes to mitochondria with Cterminal hydrophobic domain being both necessary and sufficient for its mitochondrial localization. It protects cells from TNF- $\alpha$-induced loss of mitochondrial membrane potential and apoptosis induced by vaccinia virus infection (is able to functionally replace vaccinia virus F1L) and from apoptosis induced by ectopically expressed Bak, Bax and BH3-only proteins (Banadyga et al., 2007; Banadyga et al., 2009).

When physical interaction with proapoptotic members of Bcl-2 family was assessed, binding of FPV039 with Bak,
Bax, BimL and Bik was detected (Banadyga et al., 2007, 2009).

Orf virus (ORFV) of the Parapoxvirus genus primarily infects sheep and goats, causing contagious ecthyma, but it can also infect humans. Its genome encodes for ORFV 125 (Westphal et al., 2007), a 173-aminoacid protein that contains a hydrophobic sequence on C-terminus flanked by positively charged amino acids. It contains recognizable $\mathrm{BH} 1$ and $\mathrm{BH} 3$ motifs and it also has some of the conserved residues of $\mathrm{BH} 4$ and $\mathrm{BH} 2$ motifs. Expression of ORFV125 in stably transfected cells completely prevents UV-induced apoptosis as is also observed in cells infected by ORFV. ORFV125 is targeted to mitochondria by its C-terminal domain, which is both necessary and sufficient for mitochondrial targeting, and mitochondrial localization is required for its antiapoptotic activity. It inhibits activation of Bax and Bak, and all downstream apoptotic events, including caspase activation and DNA fragmentation (Westphal et al., 2007).

To show that ORFV125 indeed acts as viral Bcl-2, mutant versions of the protein with mutations in conserved residues in $\mathrm{BH}$ motifs were tested for the antiapoptotic activity in transfected cells (Westphal et al., 2009). Results indicated that mutations that affect the activity of cellular antiapoptotic proteins also affected the activity of ORFV125.

Out of the proapoptotic BH3-only proteins, ORFV125 has been shown to bind to Bik, Puma and Bim (all three isoforms) and to weakly bind to Noxa and DP5, while no binding activity was shown to Bad, Bmf, Bid or tBid. Interestingly, ORFV125 does not bind to Bak and only binds to Bax when Bax is in active conformation, inhibiting oligomerization of active Bax (Westphal et al., 2009).

\subsection{Asfarviridae}

African swine fever virus (ASFV) is a virus that infects swine as well as soft ticks of the genus Ornithodorus that may act as a vector in virus transmission (Costa, 1990). In infected animals, it targets cells of phagocytic system, in which it induces apoptotic cell death. Apoptosis in infected cells is, however, only executed after virus replication. One of the proteins identified in ASFV that inhibit apoptosis after infection is $21 \mathrm{kDa}$ protein encoded by gene A179L (5-HL) (Neilan et al., 1993; Brun et al., 1996). This protein shows a high degree of homology to cellular Bcl-2 in all four $\mathrm{BH}$ motifs but lacks the C-terminal hydrophobic domain.

A179L appears essential for ASFV replication throughout the infection cycle. A179L has been shown to inhibit apoptosis in cultured mammalian (Afonso et al., 1996; Revilla et al., 1997) as well as insect cells (Brun et al., 1998), with this low degree of species-specificity likely enabling the protein to inhibit apoptosis both in animal (swine) and in vector (tick) cells.

Using yeast two-hybrid screen, a porcine tBid was identified as interacting $\mathrm{Bcl}-2$ family protein. When other proap- 
optotic proteins of the $\mathrm{Bcl}-2$ family were tested, A179L was shown also to interact with Bad, Bmf, Puma, Bik, Bim, Bax and Bak (Galindo et al., 2008) and very recently binding of all major proapoptotic proteins has been demonstrated (Banjara et al., 2017). Solving the structure of complexes of A179L with $\mathrm{BH} 3$ peptides of Bid or Bax thus provided important data on how proapoptotic molecules are sequestered by an antiapoptotic protein that does not discriminate among them (Banjara et al., 2017).

Similarly to herpesviral vBcl-2s, it has been shown that A179L also inhibits autophagy by interacting with Beclin-1 through its $\mathrm{BH} 3$ homology domain. A179L was found to colocalize with Beclin-1 at mitochondria and the endoplasmic reticulum. It was proposed that the localization of this viral protein to these two organelles is crucial to exert a dual function in the inhibition of apoptosis and autophagy. A179L expression inhibited autophagosomes formation in cells, however, autophagy induced prior to or at the time of virus infection significantly decreased the number of infected cells (Hernaez et al., 2013).

\subsection{Birnaviridae}

Although homologs of Bcl-2 proteins are typically found in large DNA viruses, they have also been identified in RNA viruses of the family Birnaviride. Prototypic virus of the family is infectious pancreatic necrosis virus (IPNV) that infects salmonoid fish, in which it causes infectious pancreatic necrosis. The two segment RNA genome of IPNV encodes for five major proteins, among them VP5 is a $17 \mathrm{kDa}$ protein that contains all four $\mathrm{BH}$ motifs but lacks the $\mathrm{C}$-terminal transmembrane domain (Hong et al., 2002). As for other above-mentioned vBcl-2s, when the VP5 is expressed in cultured cells, it is able to protect them from apoptosis (Hong et al., 2002). Role of the VP5 in life cycle of IPNV, however, remains unclear as studies employing mutant virus deficient in VP5 expression revealed that VP5 is not required for virulence and persistence of the virus (Santi et al., 2005b) and that it does not inhibit apoptosis induced in infected cells in vivo (Santi et al., 2005a). Here should, however, be noted that IPNV strain used in this study contains a VP5 that differs significantly from the one characterized as functional antiapoptotic protein (Hong et al., 2002) as it has substitutions in several putatively important amino acids in $\mathrm{BH} 2$ motif.

\section{Conclusions}

Viral Bcl-2 proteins provide viruses with a powerful weapon in the fight for a chance to replicate and spread. Both true homologues and proteins that lack homology in their amino acid sequences but preserve three-dimensional structure act through a shared mechanism to inhibit the per- meabilization of outer mitochondrial membrane by cellular proteins of the Bcl-2 family. Although they may primarily target different subsets of cellular proapoptotic proteins and in some cases details in binding to the target proteins may vary, their activity ultimately translates into inhibition of activation of Bax or Bak. As detailed mechanisms of how Bax and Bak permeabilize membrane, and how antiapoptotic proteins inhibit their activity, are not understood yet, many details of the action of $\mathrm{vBcl}-2$ remain to be elucidated. So does our understanding of the role of cell death inhibition by $\mathrm{vBcl}-2$ proteins in life cycles of individual viruses.

In addition to inhibition of apoptosis, some of these proteins also act as either positive or negative regulators of autophagy. Both these functions of vBcl-2 appear to be key and complementary. They suggest that these viral proteins play a fundamental role in underpinning the cellular framework for viral replication. The simplicity of the system that allows a viral protein to interact with autophagy- and apoptosis-related cellular proteins is consistent with the pertinent economy of viral material and the need to execute a vast variety of functions in the course of virus-host interactions.

Acknowledgements. This work was supported by the grant VEGA 1/0798/16 from the Scientific Grant Agency of Ministry of Education of Slovak Republic and APVV SK-FR-2015-0005 from Slovak Research and Development Agency.

\section{References}

Afonso CL, Neilan JG, Kutish GF, Rock DL, J. Virol. 70, 4858$4863,1996$.

Altmann M, Hammerschmidt W, PLoS Biol. 3, e404, 2005. https:// doi.org/10.1371/journal.pbio.0030404

Aouacheria A, Rech de Laval V, Combet C, Hardwick JM, Trends Cell. Biol. 23, 103-111, 2013. https://doi.org/10.1016/j. $\underline{\text { tcb.2012.10.010 }}$

Aoyagi M, Zhai D, Jin C, Aleshin AE, Stec B, Reed JC, Liddington RC, Protein Sci. 16, 118-124, 2007. https://doi. org/10.1110/ps.062454707

Arnoult D, Bartle LM, Skaletskaya A, Poncet D, Zamzami N, Park PU, Sharpe J, Youle RJ, Goldmacher VS, Proc. Natl. Acad. Sci. U.S.A. 101, 7988-7993, 2004. https://doi.org/10.1073/ pnas. 0401897101

Bakhshi A, Jensen JP, Goldman P, Wright JJ, McBride OW, Epstein AL, Korsmeyer SJ, Cell 41, 899-906, 1985. https://doi. org/10.1016/S0092-8674(85)80070-2

Banadyga L, Gerig J, Stewart T, Barry M, J. Virol. 81, 11032-11045, 2007. https://doi.org/10.1128/JVI.00734-07

Banadyga L, Veugelers K, Campbell S, Barry M, J. Virol. 83, 70857098, 2009. https://doi.org/10.1128/JVI.00437-09

Banjara S, Caria S, Dixon LK, Hinds MG, Kvansakul M, J. Virol. 91, pii: e02228-16, 2017. https://doi.org/10.1128/ JVI.02228-16 
Bartlett N, Symons JA, Tscharke DC, Smith GL, J. Gen. Virol. 83, 1965-1976, 2002. https://doi.org/10.1099/0022-131783-8-1965

Bellows DS, Chau BN, Lee P, Lazebnik Y, Burns WH, Hardwick JM, J. Virol. 74, 5024-5031, 2000. https://doi.org/10.1128/ JVI.74.11.5024-5031.2000

Brun A, Rivas C, Esteban M, Escribano JM, Alonso C, Virology 225, 227-230, 1996. https://doi.org/10.1006/viro.1996.0592

Brun A, Rodriguez F, Escribano JM, Alonso C, J. Virol. 72, 1022710233, 1998.

Cabras G, Decaussin G, Zeng Y, Djennaoui D, Melouli H, Broully P, Bouguermouh AM, Ooka T, J. Clin. Virol. 34, 26-34, 2005. https://doi.org/10.1016/j.jcv.2004.12.016

Cam M, Handke W, Picard-Maureau M, Brune W, Cell Death Differ. 17, 655-665, 2010. https://doi.org/10.1038/ cdd.2009.147

Campbell S, Thibault J, Mehta N, Colman PM, Barry M, Kvansakul M, J. Virol. 88, 8667-8677, 2014. https://doi.org/10.1128/ JVI.01092-14

Chaumorcel M, Lussignol M, Mouna L, Cavignac Y, Fahie K, Cotte-Laffitte J, Geballe A, Brune W, Beau I, Codogno P, Esclatine A, J. Virol. 86, 2571-2584, 2012. https://doi. org/10.1128/JVI.05746-11

Chaumorcel M, Souquere S, Pierron G, Codogno P, Esclatine A, Autophagy 4, 46-53, 2008. https://doi.org/10.4161/ auto. 5184

Cheng EH, Nicholas J, Bellows DS, Hayward GS, Guo HG, Reitz MS, Hardwick JM, Proc. Natl. Acad. Sci. U.S.A. 94, 690-694, 1997. https://doi.org/10.1073/pnas.94.2.690

Chiou SK, Tseng CC, Rao L, White E, J. Virol. 68, 6553-6566, 1994.

Chou JJ, Li H, Salvesen GS, Yuan J, Wagner G, Cell 96, 615-624, 1999. https://doi.org/10.1016/S0092-8674(00)80572-3

Cleary ML, Sklar J, Proc. Natl. Acad. Sci. U.S.A. 82, 7439-7443, 1985. https://doi.org/10.1073/pnas.82.21.7439

Coleman CB, McGraw JE, Feldman ER, Roth AN, Keyes LR, Grau KR, Cochran SL, Waldschmidt TJ, Liang C, Forrest JC, Tibbetts SA, PLoS Pathog. 10, e1003916, 2014. https:// doi.org/10.1371/journal.ppat.1003916

Cooray S, Bahar MW, Abrescia NG, McVey CE, Bartlett NW, Chen RA, Stuart DI, Grimes JM, Smith GL, J. Gen. Virol. 88, 1656-1666, 2007. https://doi.org/10.1099/vir.0.82772-0

Costa JV, In Darai G (Ed.): Molecular Biology of Iridoviruses, Norwell, MA, USA, pp. 247-270, 1990. https://doi. org/10.1007/978-1-4613-1615-2 12

Damania B, Cesarman E, In Knipe DM, Howley PM (Eds): Fields Virology. 6th ed., Wolters Kluwer Lippincott Williams \& Wilkins, Philadelphia, PA, USA, pp. 2080-2128, 2013.

de Lima BD, May JS, Marques S, Simas JP, Stevenson PG, J. Gen. Virol. 86, 31-40, 2005. https://doi.org/10.1099/ vir.0.80480-0

Desbien AL, Kappler JW, Marrack P, Proc. Natl. Acad. Sci. U.S.A. 106, 5663-5668, 2009. https://doi.org/10.1073/ pnas.0901036106

Douglas AE, Corbett KD, Berger JM, McFadden G, Handel TM, Protein Sci. 16, 695-703, 2007. https://doi.org/10.1110/ ps.062720107
E X, Hwang S, Oh S, Lee JS, Jeong JH, Gwack Y, Kowalik TF, Sun R, Jung JU, Liang C, PLoS Pathog. 5, e1000609, 2009.

Everett H, Barry M, Lee SF, Sun X, Graham K, Stone J, Bleackley RC, McFadden G, J. Exp. Med. 191, 1487-1498, 2000. https://doi.org/10.1084/jem.191.9.1487

Everett H, Barry M, Sun X, Lee SF, Frantz C, Berthiaume LG, McFadden G, Bleackley RC, J. Exp. Med. 196, 1127-1139, 2002. https://doi.org/10.1084/jem.20011247

Fleming P, Kvansakul M, Voigt V, Kile BT, Kluck RM, Huang DC, Degli-Esposti MA, Andoniou CE, PLoS Pathog. 9, e1003192, 2013. https://doi.org/10.1371/journal. ppat. 1003192

Galindo I, Hernaez B, Diaz-Gil G, Escribano JM, Alonso C, Virology 375, 561-572, 2008. https://doi.org/10.1016/j. virol.2008.01.050

Gallo A, Lampe M, Gunther T, Brune W, J. Virol. 91, pii: e01875-16, 2017. https://doi.org/10.1128/JVI.01875-16

Gangappa S, van Dyk LF, Jewett TJ, Speck SH, Virgin HWt, J. Exp. Med. 195, 931-940, 2002. https://doi.org/10.1084/ jem. 20011825

Gelgor A, Kalt I, Bergson S, Brulois KF, Jung JU, Sarid R, J. Virol. 89, 5298-5307, 2015. https://doi.org/10.1128/JVI.00098-15

Goldmacher VS, Bartle LM, Skaletskaya A, Dionne CA, Kedersha NL, Vater CA, Han JW, Lutz RJ, Watanabe S, Cahir McFarland ED, Kieff ED, Mocarski ES, Chittenden T, Proc. Natl. Acad. Sci. U.S.A. 96, 12536-12541, 1999. https://doi. org/10.1073/pnas.96.22.12536

He C, Levine B, Curr. Opin. Cell. Biol. 22, 140-149, 2010. https:// doi.org/10.1016/j.ceb.2010.01.001

Henderson S, Huen D, Rowe M, Dawson C, Johnson G, Rickinson A, Proc. Natl. Acad. Sci. U.S.A. 90, 8479-8483, 1993. https://doi.org/10.1073/pnas.90.18.8479

Hernaez B, Cabezas M, Munoz-Moreno R, Galindo I, Cuesta-Geijo MA, Alonso C, Curr. Mol. Med. 13, 305-316, 2013. https:// doi.org/10.2174/156652413804810736

Hinds MG, Smits C, Fredericks-Short R, Risk JM, Bailey M, Huang DC, Day CL, Cell Death Differ. 14, 128-136, 2007. https:// doi.org/10.1038/sj.cdd.4401934

Hong JR, Gong HY, Wu JL, Virology 295, 217-229, 2002. https:// doi.org/10.1006/viro.2001.1336

Hsu WL, Chung PJ, Tsai MH, Chang CL, Liang CL, Virus Res. 163, 617-627, 2012. https://doi.org/10.1016/j. virusres.2011.12.017

Hsu YT, Wolter KG, Youle RJ, Proc. Natl. Acad. Sci. U.S.A. 94, 36683672, 1997. https://doi.org/10.1073/pnas.94.8.3668

Huang Q, Petros AM, Virgin HW, Fesik SW, Olejniczak ET, J. Mol. Biol. 332, 1123-1130, 2003. https://doi.org/10.1016/j. jmb.2003.08.007

Kaufmann T, Schlipf S, Sanz J, Neubert K, Stein R, Borner C, J. Cell. Biol. 160, 53-64, 2003. https://doi.org/10.1083/ jcb. 200210084

Ku B, Woo JS, Liang C, Lee KH, Hong HS, E X, Kim KS, Jung JU, Oh BH, PLoS Pathog. 4, e25, 2008. https://doi.org/10.1371/ journal.ppat.0040025

Kvansakul M, Wei AH, Fletcher JI, Willis SN, Chen L, Roberts AW, Huang DC, Colman PM, PLoS Pathog. 6, e1001236, 2010. https://doi.org/10.1371/journal.ppat.1001236 
Kvansakul M, Yang H, Fairlie WD, Czabotar PE, Fischer SF, Perugini MA, Huang DC, Colman PM, Cell Death Differ. 15, 15641571, 2008. https://doi.org/10.1038/cdd.2008.83

Levine B, Deretic V, Nat. Rev. Immunol. 7, 767-777, 2007. https:// doi.org/10.1038/nri2161

Liang C, E X, Jung JU, Autophagy 4, 268-272, 2008. https://doi. org/10.4161/auto.5210

Liang C, Oh BH, Jung JU, Nat. Rev. Microbiol. 13, 7-12, 2015 a. https://doi.org/10.1038/nrmicro3369

Liang Q, Chang B, Lee P, Brulois KF, Ge J, Shi M, Rodgers MA, Feng P, Oh BH, Liang C, Jung JU, J. Virol. 89, 5308-5317, 2015b. https://doi.org/10.1128/JVI.00102-15

Lindsten T, Ross AJ, King A, Zong WX, Rathmell JC, Shiels HA, Ulrich E, Waymire KG, Mahar P, Frauwirth K, Chen Y, Wei M, Eng VM, Adelman DM, Simon MC, Ma A, Golden JA, Evan G, Korsmeyer SJ, MacGregor GR, Thompson CB, Mol. Cell 6, 1389-1399, 2000. https://doi.org/10.1016/ S1097-2765(00)00136-2

Loh J, Huang Q, Petros AM, Nettesheim D, van Dyk LF, Labrada L, Speck SH, Levine B, Olejniczak ET, Virgin HWt, PLoS Pathog. 1, e10, 2005. https://doi.org/10.1371/journal. ppat. 0010010

Longnecker RM, Kieff E, Cohen JI, In Knipe DM, Howley PM (Eds): Fields Virology. 6th ed., Wolters Kluwer Lippincott Williams \& Wilkins, Philadelphia, PA, USA, pp. 1898-1959, 2013.

Ma J, Edlich F, Bermejo GA, Norris KL, Youle RJ, Tjandra N, Proc. Natl. Acad. Sci. U.S.A. 109, 20901-20906, 2012. https:// doi.org/10.1073/pnas.1217094110

Maluquer de Motes C, Cooray S, Ren H, Almeida GM, McGourty K, Bahar MW, Stuart DI, Grimes JM, Graham SC, Smith GL, PLoS Pathog. 7, e1002430, 2011. https://doi.org/10.1371/ journal.ppat.1002430

Manzur M, Fleming P, Huang DC, Degli-Esposti MA, Andoniou CE, Cell Death Differ. 16, 312-320, 2009. https://doi. org/10.1038/cdd.2008.152

Marques S, Efstathiou S, Smith KG, Haury M, Simas JP, J. Virol. 77, 7308-7318, 2003. https://doi.org/10.1128/JVI.77.13.7308$\underline{7318.2003}$

Marshall WL, Yim C, Gustafson E, Graf T, Sage DR, Hanify K, Williams L, Fingeroth J, Finberg RW, J. Virol. 73, 5181$5185,1999$.

Mavinakere MS, Williamson CD, Goldmacher VS, Colberg-Poley AM, J. Virol. 80, 6771-6783, 2006. https://doi.org/10.1128/ JVI.00492-06

McDonnell JM, Fushman D, Milliman CL, Korsmeyer SJ, Cowburn D, Cell 96, 625-634, 1999. https://doi.org/10.1016/S00928674(00)80573-5

Mocarski ES, Shenk T, Griffiths PD, F. Pass RF, In Knipe DM, Howley PM (Eds): Fields Virology. 6th ed., Wolters Kluwer Lippincott Williams \& Wilkins, Philadelphia, PA, USA, pp. 1960-2014, 2013.

Muchmore SW, Sattler M, Liang H, Meadows RP, Harlan JE, Yoon HS, Nettesheim D, Chang BS, Thompson CB, Wong SL, Ng SL, Fesik SW, Nature 381, 335-341, 1996. https://doi. org/10.1038/381335a0

Neilan JG, Lu Z, Afonso CL, Kutish GF, Sussman MD, Rock DL, J. Virol. 67, 4391-4394, 1993.
Nowag H, Guhl B, Thriene K, Romao S, Ziegler U, Dengjel J, Munz C, EBioMedicine 1, 116-125, 2014. https://doi. org/10.1016/j.ebiom.2014.11.007

Opgenorth A, Graham K, Nation N, Strayer D, McFadden G, J. Virol. 66, 4720-4731, 1992.

Pattingre S, Tassa A, Qu X, Garuti R, Liang XH, Mizushima N, Packer M, Schneider MD, Levine B, Cell 122, 927-939, 2005. https://doi.org/10.1016/j.cell.2005.07.002

Pauleau AL, Larochette N, Giordanetto F, Scholz SR, Poncet D, Zamzami N, Goldmacher VS, Kroemer G, Oncogene 26, 7067-7080, 2007. https://doi.org/10.1038/ sj.onc. 1210511

Piya S, White EJ, Klein SR, Jiang H, McDonnell TJ, Gomez-Manzano C, Fueyo J, PLoS One 6, e29467, 2011. https://doi. org/10.1371/journal.pone.0029467

Postigo A, Cross JR, Downward J, Way M, Cell Death Differ. 13, 1651-1662, 2006. https://doi.org/10.1038/ sj.cdd. 4401853

Procko E, Berguig GY, Shen BW, Song Y, Frayo S, Convertine AJ, Margineantu D, Booth G, Correia BE, Cheng Y, Schief WR, Hockenbery DM, Press OW, Stoddard BL, Stayton PS, Baker D, Cell 157, 1644-1656, 2014. https://doi. org/10.1016/j.cell.2014.04.034

Revilla Y, Cebrian A, Baixeras E, Martinez C, Vinuela E, Salas ML, Virology 228, 400-404, 1997. https://doi.org/10.1006/ viro.1996.8395

Santi N, Sandtro A, Sindre H, Song H, Hong JR, Thu B, Wu JL, Vakharia VN, Evensen O, Virology 342, 13-25, 2005 a. https://doi.org/10.1016/j.virol.2005.07.028

Santi N, Song H, Vakharia VN, Evensen O, J. Virol. 79, 9206 9216, 2005b. https://doi.org/10.1128/JVI.79.14.9206$\underline{9216.2005}$

Sarid R, Sato T, Bohenzky RA, Russo JJ, Chang Y, Nat. Med. 3, 293 298, 1997. https://doi.org/10.1038/nm0397-293

Sattler M, Liang H, Nettesheim D, Meadows RP, Harlan JE, Eberstadt M, Yoon HS, Shuker SB, Chang BS, Minn AJ, Thompson CB, Fesik SW, Science 275, 983-986, 1997. https://doi.org/10.1126/science.275.5302.983

Sinha S, Colbert CL, Becker N, Wei Y, Levine B, Autophagy 4, 989 997, 2008. https://doi.org/10.4161/auto.6803

Smith JD, de Harven E, J. Virol. 26, 102-109, 1978.

Stewart TL, Wasilenko ST, Barry M, J. Virol. 79, 1084-1098, 2005. https://doi.org/10.1128/JVI.79.2.1084-1098.2005

Su J, Wang G, Barrett JW, Irvine TS, Gao X, McFadden G, J. Virol. 80, 1140-1151, 2006. https://doi.org/10.1128/JVI.80.3.1140$\underline{1151.2006}$

Subramanian T, Boyd JM, Chinnadurai G, Oncogene 11, 24032409, 1995a.

Subramanian T, Tarodi B, Chinnadurai G, Curr. Top. Microbiol. Immunol. 199, 153-161, 1995b. https://doi.org/10.1007/9783-642-79496-4 9

Suzuki M, Youle RJ, Tjandra N, Cell 103, 645-654, 2000. https:// doi.org/10.1016/S0092-8674(00)00167-7

Taylor JM, Quilty D, Banadyga L, Barry M, J. Biol. Chem. 281, 39728-39739, 2006. https://doi.org/10.1074/jbc. $\underline{\mathrm{M} 607465200}$

Tsujimoto Y, Cossman J, Jaffe E, Croce CM, Science 228, 1440-1443, 1985. https://doi.org/10.1126/science. 3874430 
Virgin HWt, Presti RM, Li XY, Liu C, Speck SH, J. Virol. 73, 23212332, 1999.

Wang G, Barrett JW, Nazarian SH, Everett H, Gao X, Bleackley C, Colwill K, Moran MF, McFadden G, J. Virol. 78, 7097-7111, 2004. https://doi.org/10.1128/JVI.78.13.7097-7111.2004

Wang GH, Garvey TL, Cohen JI, J. Gen. Virol. 80, 2737-2740, 1999. https://doi.org/10.1099/0022-1317-80-10-2737

Wasilenko ST, Banadyga L, Bond D, Barry M, J. Virol. 79, 1403114043, 2005. https://doi.org/10.1128/JVI.79.22.14031$\underline{14043.2005}$

Wasilenko ST, Stewart TL, Meyers AF, Barry M, Proc. Natl. Acad. Sci. U.S.A. 100, 14345-14350, 2003. https://doi. org/10.1073/pnas.2235583100

Wei MC, Zong WX, Cheng EH, Lindsten T, Panoutsakopoulou V, Ross AJ, Roth KA, MacGregor GR, Thompson CB, Korsmeyer SJ, Science 292, 727-730, 2001. https://doi. org/10.1126/science. 1059108

Wei Y, Pattingre S, Sinha S, Bassik M, Levine B, Mol. Cell. 30, 678688, 2008. https://doi.org/10.1016/j.molcel.2008.06.001

Westphal D, Ledgerwood EC, Hibma MH, Fleming SB, Whelan EM, Mercer AA, J. Virol. 81, 7178-7188, 2007. https:// doi.org/10.1128/JVI.00404-07

Westphal D, Ledgerwood EC, Tyndall JD, Hibma MH, Ueda N, Fleming SB, Mercer AA, Apoptosis 14, 1317-1330, 2009. https://doi.org/10.1007/s10495-009-0403-1

White E, Cipriani R, Sabbatini P, Denton A, J. Virol. 65, 29682978, 1991.
White E, Grodzicker T, Stillman BW, J. Virol. 52, 410-419, 1984.

White E, Sabbatini P, Debbas M, Wold WS, Kusher DI, Gooding LR, Mol. Cell. Biol. 12, 2570-2580, 1992. https://doi. org/10.1128/MCB.12.6.2570

Williamson CD, Zhang A, Colberg-Poley AM, J. Virol. 85, 21002111, 2011. https://doi.org/10.1128/JVI.01830-10

Willis SN, Adams JM, Curr. Opin. Cell Biol. 17, 617-625, 2005. https://doi.org/10.1016/j.ceb.2005.10.001

Wolter KG, Hsu YT, Smith CL, Nechushtan A, Xi XG, Youle RJ, J. Cell Biol. 139, 1281-1292, 1997. https://doi.org/10.1083/ jcb.139.5.1281

Yang Z, Klionsky DJ, Curr. Opin. Cell Biol. 22, 124-131, 2010. https://doi.org/10.1016/j.ceb.2009.11.014

Yee J, White RE, Anderton E, Allday MJ, PLoS One 6, e28506, 2011. https://doi.org/10.1371/journal.pone.0028506

Youle RJ, Strasser A, Nat. Rev. Mol. Cell Biol. 9, 47-59, 2008. https:// doi.org/10.1038/nrm2308

Yu E, Zhai D, Jin C, Gerlic M, Reed JC, Liddington R, J. Biol. Chem. 286, 30748-30758, 2011. https://doi.org/10.1074/ jbc.M111.280149

Zha J, Weiler S, Oh KJ, Wei MC, Korsmeyer SJ, Science 290, 1761-1765, 2000. https://doi.org/10.1126/science.290.5497.1761

Zhai D, Yu E, Jin C, Welsh K, Shiau CW, Chen L, Salvesen GS, Liddington R, Reed JC, J. Biol. Chem. 285, 5569-5580, 2010. https://doi.org/10.1074/jbc.M109.078113

Zhang A, Hildreth RL, Colberg-Poley AM, J. Virol. 87, 5657-5668, 2013. https://doi.org/10.1128/JVI.00145-13 